\title{
Simple tools for projecting patient recruitment
}

\author{
Paul Silcocks \\ From 2nd Clinical Trials Methodology Conference: Methodology Matters \\ Edinburgh, UK. 18-19 November 2013
}

Poor recruitment to clinical trials is a well-recognised and serious problem. Various predictors of poor recruitment have been identified and of course should be accounted for in trial design. Trial planning however will need a realistic projection of sample recruitment that also allows for random variation - yet available information may be minimal early in the development of a proposal. Such projections are also required when estimating power for survival analyses (the yield of events depends both on numbers and timing of patient accrual) - for example if using the Stata add-on artsurv.

I show here how minimal information, simple formulae and some reasonable assumptions can be combined to estimate both a sensible projection of expected numbers and a plausible range of variation; in turn this variation indicates the extent to which achieving the target sample size may be delayed. Simple calculations also indicate potential gains from restricting eligibility to betterperforming sites and the relative lack of benefit from opening better-performing sites first.

Published: 29 November 2013

doi:10.1186/1745-6215-14-S1-P137

Cite this article as: Silcocks: Simple tools for projecting patient

recruitment. Trials 2013 14(Suppl 1):P137.

CRUK Liverpool Cancer Trials Unit, Liverpool, UK

Submit your next manuscript to BioMed Central and take full advantage of:

- Convenient online submission

- Thorough peer review

- No space constraints or color figure charges

- Immediate publication on acceptance

- Inclusion in PubMed, CAS, Scopus and Google Scholar

- Research which is freely available for redistribution

\section{Biomed Central}

(c) 2013 Silcocks; licensee BioMed Central Ltd. This is an Open Access article distributed under the terms of the Creative Commons Attribution License (http://creativecommons.org/licenses/by/2.0), which permits unrestricted use, distribution, and reproduction in any medium, provided the original work is properly cited. 